\title{
DISCOVERY OF NEW TARGETS FOR ANTIMALARIAL CHEMOTHERAPY
}

\author{
GRELLIER P.*, DEPOIX D.*, SCHRÉVEL J.* \& FLORENT I.*
}

\section{Summary:}

The understanding of the biology and the biochemistry of malaria parasites has considerably increased over the past two decades with the discovery of many potential targets for new antimalarial drugs. The decrypted genomes of several Plasmodium species and the new post-genomic tools further enriched our "reservoir" of targets and increased our ability to validate potential drug targets or to study the entire parasite metabolism. This review discusses targets involved in calcium metabolism, protein prenylation and apicoplast functions that have emerged by different approaches.

KEY WORDS : antimalarials, drug targets, artemisinin, SERCA, apicoplast, isoprenoid, haem, farnesyltransferase.

M alaria, caused by the protozoa Plasmodium, is the most deadly parasitic infectious disease worldwide with 300-500 million cases and 2.73 million death per year, in majority among children ( $<5$ years old). Today, the chemotherapeutic arsenal for malaria treatments is limited to three main families of compounds: the quinolines (quinine, chloroquine, mefloquine...), the antifolates (sulfadoxine, pyrimethamine...) and the artemisinin derivatives. Widespread drug resistance resulted in the ineffectiveness of many antimalarials and chemotherapy now requires drug combinations. The understanding of the biology and the biochemistry of malaria parasites has increased considerably over the past two decades, as well as the understanding of the mechanisms of action and resistance of antimalarials (Woodrow \& Krishna, 2006). Many potential targets for new drugs were identified (Table I). The decrypted genomes of several Plasmodium species further enriched the "reservoir" of putative targets either because they were homologous to validated targets in other organisms, or because they were species specific, with no homologous counterpart. Furthermore, recent advances in genetic manipulation of Plasmodium greatly increased the ability to validate potential drug targets and the access to trans-

\footnotetext{
* National Museum of Natural History, USM504-EA3335, Functional biology of protozoa, Department RDDM, CP 52, 61, rue Buffon, F-75231 Paris Cedex 05, France.

Correspondence: Philippe Grellier.

Tel.: +33 (0)1 40793510 - Fax: +33 (0)1 40793499 .

E-mail: grellier@mnhn.fr
}

criptome and proteome analysis offered new opportunities to study the entire parasite metabolism. Highthroughput bioassays against these targets are becoming more accessible to the academic laboratories and allow to screen a large diversity of molecules issued either from pharmaceutical or natural product libraries, which may provide lead molecules for new antimalarial drugs (Mambu \& Grellier, 2007). In this report, we review some of these newly identified targets for antimalarial chemotherapy.

\section{SARCOPLASMIC/ENDOPLASMIC RETICULUM CALCIUM PFATPase (SERCA)}

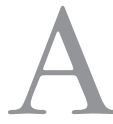
rtemisinin and its derivatives are key antimalaria agents constituting the foundation of the ACT 1 - (artemisinin-based combination therapy) strategy developed by WHO against malaria. Understanding how artemisinins work is particularly important to prevent the emergence of resistant parasites. Indeed, there are accumulating evidences for increasing artemisinin resistance in vitro of $P$. falciparum isolates (Jambou et al., 2005) and reduced in vitro susceptibility to dihydroartemisinin and recrudescence have been observed after artesunate monotherapy (Menard et al., 2005). However and fortunately, no clear clinical resistance was reported. The mechanism(s) of action and the cellular target(s) for artemisinins remain controversial (Golenser et al., 2006; Krishna et al., 2006). Artemisinins are fast acting agents, the endoperoxide bridge being the key pharmacophore. It was commonly proposed that iron contained in parasite haem reacted with the peroxide moiety leading to production of free radicals, haem-artemisinin adducts and alkylation of proteins, resulting in parasite damage. This multiple-target mechanism of action of artemisinin was supported, until now, by the lack of evidence for artemisinin resistance. It was also suggested that the electron transport chain of $P$. falciparum might be a target for artemisinin. However, several reports supported that artemisinin activity was outside the parasite food vacuole that contains haem and in fact the sarco-endoplasmic reti- 


\begin{tabular}{|c|c|c|c|}
\hline Target & Enzyme/processs & Inhibitor & \\
\hline Food vacuole & $\begin{array}{l}\text { Haem polymerization } \\
\text { Production of reactive species }\end{array}$ & $\begin{array}{l}\text { Quinolines } \\
\text { Artemisinins } \\
\text { Trioxaquines } \\
\text { Trioxolanes }\end{array}$ & $\begin{array}{l}\text { (O'Neill et al., 2006) } \\
\text { (Benoit-Vical et al., 2007; Golenser et } \\
\text { al., 2006; Vennerstrom et al., 2004) }\end{array}$ \\
\hline Pyrimidine metabolism & $\begin{array}{l}\text { Orotate phosphoribosyltransferase, } \\
\text { Thymidylate synthase }\end{array}$ & 5'-substituted orotate analogues & (Hyde, 2007) \\
\hline Folate metabolism & $\begin{array}{l}\text { Dihydrofolate reductase } \\
\text { Dihydropteroate synthase }\end{array}$ & $\begin{array}{l}\text { Pyrimethamine, proguanil } \\
\text { Sulfonamides }\end{array}$ & (Hyde, 2007) \\
\hline Purine metabolism & $\begin{array}{l}\text { Adenosine deaminase } \\
\text { Purine nucleoside phosphorylase } \\
\text { Hypoxanthine/xanthine/guanine } \\
\text { phosphoribosyltransferase }\end{array}$ & $\begin{array}{l}\text { Adenosine analogues } \\
\text { Immucillins } \\
\text { 5'-phosphorylated immucillins }\end{array}$ & (Hyde, 2007) \\
\hline Mitochondrion & Electron transport chain & $\begin{array}{l}\text { Coenzyme Q analogues: } \\
\text { Atovaquone }\end{array}$ & (Mather et al., 2007) \\
\hline Lipid metabolism & $\begin{array}{l}\text { Glycerophospholipid synthesis } \\
\text { Sphingolipid metabolism } \\
\text { Non-mevalonate pathway: DOXP } \\
\text { reductoisomerase }\end{array}$ & $\begin{array}{l}\text { Choline analogues: G25 } \\
\text { Ceramide analogues } \\
\text { Fosmidomycin }\end{array}$ & $\begin{array}{l}\text { (Wengelnik et al., 2002) } \\
\text { (Labaied et al., 2004) } \\
\text { (Wiesner \& Jomaa, 2007) }\end{array}$ \\
\hline & $\begin{array}{l}\text { Type II fatty acid synthase system: } \\
\beta \text {-ketoacyl-ACP synthase } \\
\text { Enoyl-ACP-reductase }\end{array}$ & $\begin{array}{l}\text { Thiolactomycin } \\
\text { Triclosan }\end{array}$ & $\begin{array}{l}\text { (Surolia \& Surolia, 2001; Waller et al., } \\
\text { 1998) }\end{array}$ \\
\hline Shikimate pathway & $\begin{array}{l}\text { 5-enolpyruvylshikimate } 3 \text { - } \\
\text { phosphate synthase }\end{array}$ & Glyphosate & (McRobert et al., 2005) \\
\hline Apicoplast & $\begin{array}{l}\text { Replication, transcription, } \\
\text { translation }\end{array}$ & $\begin{array}{l}\text { Quinolone antibiotics, } \\
\text { rifampicin, tetracycline related } \\
\text { antibiotics, clindamycin }\end{array}$ & (Sato \& Wilson, 2005) \\
\hline Redox homeostasis & $\begin{array}{l}\text { Glutathione reductase } \\
\text { Thioredoxin reductase }\end{array}$ & Methylene blue, naphthoquinones & $\begin{array}{l}\text { (Bauer et al., 2006; Schirmer et al., } \\
\text { 2003) }\end{array}$ \\
\hline Protein prenylation & Protein farnesyltransferase & Tetrahydroquinolines & (Van Voorhis et al., 2007) \\
\hline Proteases & $\begin{array}{l}\text { Haemoglobin degradation: } \\
\text { Plasmepsins, falcipains } \\
\text { Erythrocyte invasion } \\
\text { Amino- and exopeptidases }\end{array}$ & $\begin{array}{l}\text { Leupeptin, pepstatin, vinyl } \\
\text { sulfones, calpain inhibitors, } \\
\text { transition stage analogues, } \\
\text { E-64, allicin } \\
\text { Bestatin, dipeptide analogues, } \\
\text { malonic hydoxamates }\end{array}$ & $\begin{array}{l}\text { (Flipo et al., 2007; Goldberg, 2005; } \\
\text { O'Donnell \& Blackman, 2005) }\end{array}$ \\
\hline Calcium metabolism & $\begin{array}{l}\text { Sacroplasmic/endoplasmic } \\
\text { Reticulum calcium ATPase }\end{array}$ & $\begin{array}{l}\text { Artemisinins } \\
\text { Trioxolanes }\end{array}$ & (Eckstein-Ludwig et al., 2003) \\
\hline Kinases & $\begin{array}{l}\text { Cyclin-dependent protein kinases, } \\
\text { Pfnek-1, Pfcrk-1, Pfmrk }\end{array}$ & $\begin{array}{l}\text { Purine analogues, quinolinones, } \\
\text { isoquinoline sulfonamides, } \\
\text { oxindoles, chalcones }\end{array}$ & (Doerig \& Meijer, 2007) \\
\hline
\end{tabular}

Table 1. - Targets for antimalarial chemotherapy.

culum $\mathrm{Ca}^{2+}$-ATPase (SERCA) of P. falciparum (PfATP6) might be the primary target of artemisinins (EcksteinLudwig et al., 2003). SERCA is responsible for the maintenance of calcium ion concentrations, which is essential for cell survival. Artemisinin is structurally similar to thapsigargin, a SERCA inhibitor. Three-dimensional modelling and docking simulation demonstrated that artemisinin bound to SERCA by hydrophobic interactions leaving the peroxide bonds exposed and accessible to cleavage by iron, leading to enzyme inactivation and parasite death (Jung et al., 2005). This was supported by a single amino acid mutation (L263E) in parasite SERCA expressed in X. laevis oocytes that modulated sensitivity to artemisinin (Uhlemann et al., 2005) and by a single nucleotide polymorphism (S769N) associated to reduced in vitro artemether susceptibility in French Guiana isolates (Jambou et al., 2005). How this last mutation interferes with the artemether action remains unclear.
Even if at present no decisive evidence favours a main mechanism of action for artemisinins (if there is a major one), SERCA by its important role in calcium homeostasis emerges as a potential new target for antimalarial development. Calcium controls vital processes in cells but little is known about mechanisms controlling $\mathrm{Ca}^{2+}$ homeostasis and signalling in Plasmodium. A recent genomic and phylogenic comparison revealed that apicomplexa contain unusual calcium response pathways that need deeper investigations and could be exploited as new therapeutic agents (Nagamune \& Sibley, 2006).

\section{PROTEIN PRENYLATION IN P. FALCIPARUM}

$\mathrm{P}$ renylated proteins play essential functions in many cellular processes including vesicular trafficking, signal transduction and regulation of DNA replication as well as cell cycle. Such post-translational modi- 
fications allow to anchor proteins to membranes and to promote protein-protein interactions (i.e. for the Ras superfamily G-proteins). Prenyltranferases are enzymes catalyzing the addition of lipid moieties to proteins and are currently considered as potential targets in cancer therapy. Several candidate compounds targeting prenyltransferases show a great promise as antitumor agents. Well tolerated in man, they are currently being tested in clinical trials. In mammals, protein farnesyltransferase (PFT) transfers a 15 -carbone isoprenoid unit, a farnesyl group, from farnesyl pyrophosphate to the cysteine in the C-terminal motif CaaX (C: cysteine, a: usually aliphatic amino acid, X: preferentially methionine, glutamine, serine). Protein geranylgeranyltransferase-I (PGGT-I) attaches a geranylgeranyl (20-carbone unit) group from geranylgeranyl phosphate to the cysteine of a C-terminal motif CaaL/F. PGGT-II adds two geranylgeranyl groups to the $\mathrm{C}$-terminal sequences $\mathrm{CC}$, CXC and CCXX.

Protein prenylation has been demonstrated in parasites such as Giardia, Trypanosoma, Leishmania, Toxoplasma and Plasmodium. PFT has been particularly well studied in Trypanosoma brucei and Plasmodium falciparum: differences between the active sites of parasite versus mammalian PFTs pointed to parasite PFTs as potential drug targets (Gelb et al., 2003). Furthermore, interest was strengthened by the fact that peptidomimetics and prenyl analogues of PFT substrates were shown to inhibit in vitro parasite growth (Chakrabarti et al., 2002; Ohkanda et al., 2001). Although the PGGT-I activity was reported, searches in the $P$. falciparum genome database revealed an apparent absence of PGGT-I gene (Nallan et al., 2005).

Because of their anticancer properties, PFT inhibitors are well developed by the pharmaceutical industry. A "piggy-back" approach using the chemical compounds and pharmacological data from industry allowed to develop tetrahydroquinoline (THQ)-based PFT inhibitors inhibiting the $P$. falciparum PFT and the in vitro growth of different parasite strains with low nanomolar concentrations (Nallan et al., 2005). Growth inhibition was correlated to the inhibition of protein farnesylation in cultured malaria parasites and to cellular localization changes of prenylated proteins, supporting PFT as the target of THQs. In vivo, in $P$. berghei-infected mice, the lead compound (delivered in blood using pumps) delayed the onset of parasitemia and eradicated parasites in $60 \%$ of mice for a concentration of $200 \mathrm{mg}$ / $\mathrm{kg} /$ day. No toxicity was observed in treated animals. A series of piperazinyl PFT inhibitors were also reported to inhibit the in vitro growth of P. falciparum (correlated with a reduction of protein prenylation) and the in vivo growth of $P$. berghei (delivered intraperitoneally) (Wiesner et al., 2004). Efforts are now underway to optimize the water solubility, the bioavailability and the pharmacokinetic properties of PFT inhibitors (Van
Voorhis et al., 2007). As well, these studies underlined the important role of farnesylated proteins in $P$. falciparum life cycle, and the need to identify and characterize these potential new targets.

A P. falciparum clone resistant to the THQ PFT inhibitor BMS-388891 was experimentally obtained under drug pressure (Eastman et al., 2005). This resistance was associated with a single point mutation (adenine $>$ guanine) in the gene coding for the $\beta$ subunit of PFT that changed a tyrosine for a cysteine in position 837 , predicted to be in the peptide binding pocket. This mutation led to a decreased affinity of PFT for BMS-388891. Homology model of Plasmodium PFT based on the crystal structure of rat PFT and docking of BMS-388891 supported the importance of the mutation Y837C in the resistance. In a recent work, the resistance of $P$. falciparum to a different THQ inhibitor BMS-339941 also revealed a single point mutation in the $\beta$ subunit of PFT (G612A) near the farnesyl pyrophosphate binding site and cross-resistance to other THQ inhibitors was observed (Eastman et al., 2007). Such a rapid emergence of resistance limits the potential of THQ PFT inhibitors as antimalarial agents. They, as well as all future antimalarials, will need to be used in combination with other drugs to decrease the occurrence of resistance. The Y837C mutation arised independently at least twice in $3 \times 10^{8}$ parasites in vitro suggesting that this mutation could arise multiple times in an infected person (Eastman et al., 2005).

\section{TARGETING APICOPLAST FUNCTIONS}

T ong time considered as an enigmatic single-copy organelle surrounded by 3-4 membranes and $\checkmark$ found in numerous apicomplexa, the apicoplast revealed during this last decade interesting properties for the development of chemotherapeutic agents (Sato \& Wilson, 2005). It probably evolved as a result of secondary endosymbiosis of a prokaryote, which seems to have a cyanobacterial origin, by an ancestor of the apicomplexa, leading to an organelle that maintains a separate $35-\mathrm{kb}$ genome and some specific functions. Protein synthesis occurs in apicoplast but relatively few RNAs and proteins are specified by the apicoplast genome itself (essentially components for the organelle protein synthesis), the other products being encoded by the nuclear genome that has acquired most of the original genes during the parasite evolution. Apicoplast proteins are thus primarily synthesised in parasite cytosol and post-translationally targeted to the apicoplast using a bipartite signal consisting of a classical eukaryotic signal peptide and a plant-like transit peptide. Based on these characteristics, 466 nuclearly encoded proteins were predicted to be targeted to this organelle (Foth et al., 2003), although, up to now, the import of 
very few proteins has been demonstrated by genetic approaches or by detecting their enzymatic activities. Apicoplast possesses specific biochemical pathways for synthesis of fatty acids, isoprenoids, haem as well as for DNA replication and protein synthesis that are present in bacteria and plants but are absent in humans thereby providing specific targets for antimalarial drugs.

\section{FATTY ACID PATHWAY}

$P$. falciparum synthesizes fatty acids with the type II fatty acid synthase system (FAS II), which consists of six separate enzymes, and that is widespread among bacteria and eukaryotic plastids (Fig. 1). In contrast, animals and humans have the type I fatty acid synthase (FAS I), which is a multi-functional polypeptide carrying all the enzymatic activities. FAS I seems to be absent from $P$. falciparum in contrast to other apicomplexa such as Cryptosporidium parvum, which has no plastid and only FAS I, and Toxoplasma gondii, which possesses both fatty acids systems. Surprisingly, no FAS I and FAS II pathways were identified in Theileria indicating that apicomplexa have maintained different fatty acid-biosynthetic pathways according to the adaptation to their host cell niches (Mazumdar \& Striepen, 2007). Interestingly, the natural antibiotic thiolactomycin is an inhibitor of $\beta$-ketoacyl-ACP synthases of FAS II (FabH, FabB/F) and was shown to inhibit $P$. falciparum in cul- ture (Waller et al., 1998). As well, the antimicrobial Triclosan, a specific inhibitor of the enoyl-ACP-reductases (PfENR or FabI) of FAS II, inhibits $P$. falciparum in vitro and can cure Plasmodium-infected mice (Surolia \& Surolia, 2001). X-ray structural analysis of PfENR has expanded the knowledge of the structure-activity relationships of Triclosan. This leads to analogues active in low micromolar range in vitro on $P$. falciparum and displaying a higher affinity for PfENR (Freundlich et al., 2007).

\section{ISOPRENOID PATHWAY}

In humans and fungus, this pathway generates isopentyl diphosphate from mevalonate, an intermediate of the synthesis of important biomolecules (sterols, dolichols, vitamins A, E, coenzyme Q...). Despite the fact that $P$. falciparum does not synthesize cholesterol, isoprenoid metabolism is critical for parasite development as evidenced by the PFT studies. Unlike humans, Plasmodium synthesizes isoprenoids using 1-deoxy-Dxylulose-5-phosphate (DOXP) as precursor. This nonmevalonate pathway or methyl erythritol phosphate biosynthetic pathway was previously found in eubacteria and plants but was absent in humans constituting a good target for antimalarials (Wiesner \& Jomaa, 2007). One enzyme of this pathway, the DOXP reductoisomerase, is specifically inhibited by fosmidomycin,

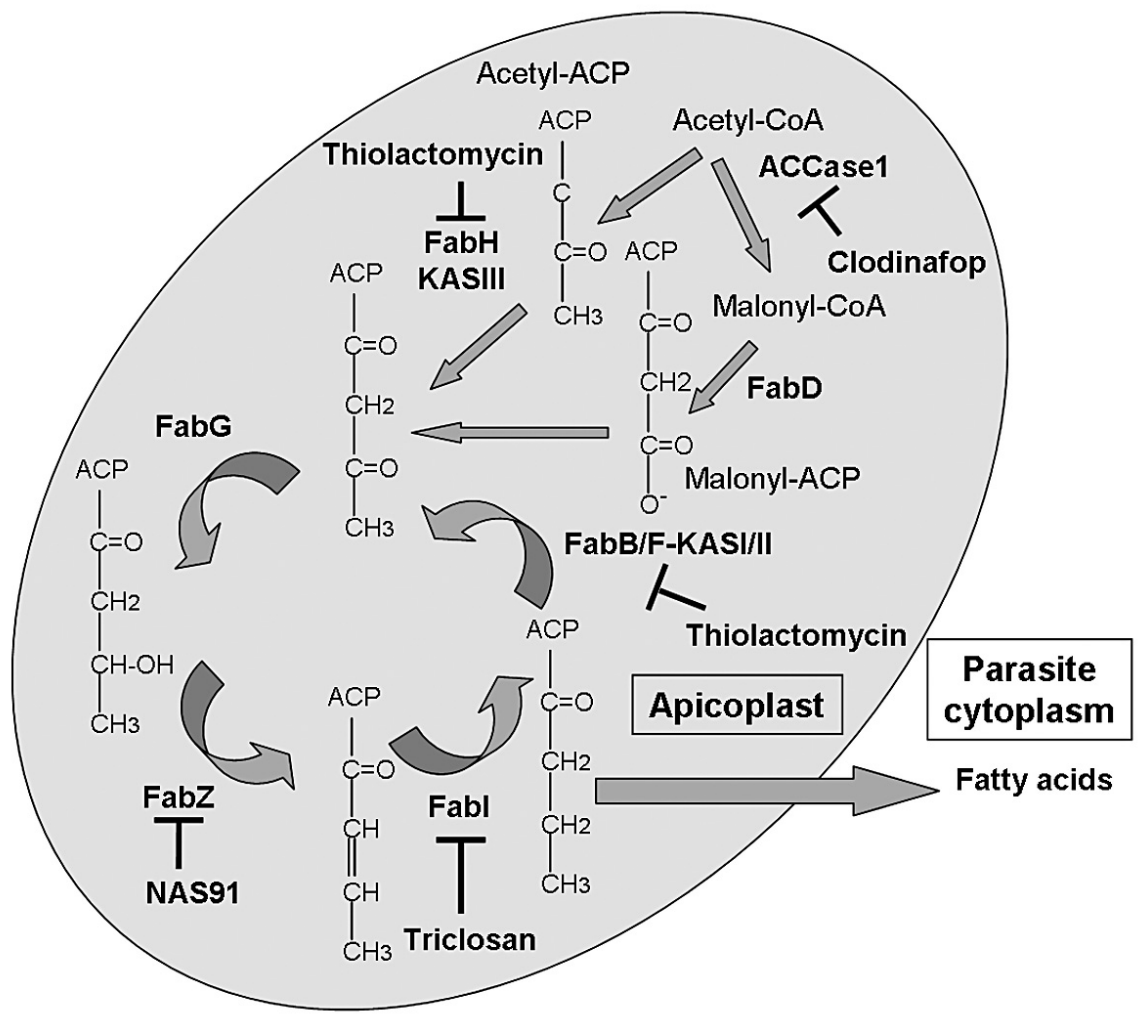

Fig. 1. - Type II fatty acid synthesis pathway in apicoplast.

The glycolysis product phosphoenolpyruvate is imported into the apicoplast and converted to acetyl-Coenzyme A (CoA) by the pyruvate kinase and the pyruvate dehydrogenase. Malonyl-CoA is produced from the acetyl-CoA by the acetyl-CoA carboxylase 1 (ACCase1). Acetyl-CoA and malonyl-CoA are transfered to the acyl carrier protein (ACP) by FabD and condensed by the $\beta$-ketoacyl-ACP synthase FabH (or KASIII). Reduction by the $\beta$-ketoacyl-ACP reductase FabG and dehydratation by the $\beta$-hydroxyacyl-ACP dehydratase FabZ, followed by reduction by the enoyl-ACP reductase FabI conduct to reduced acyl chain. A new round of reduction is initiated by condensation of the acyl chain to malonyl-ACP by the $\beta$ ketoacyl-ACP synthase FabF/B (or KASI/II). Repetition of this process leads to lengthening chain. Fatty acids are transported to the parasite cytoplasm for elongation and used for phospholipid biosynthesis. Several compounds inhibit FASII enzymes: the aryloxyphenoxypropionate derivatives as the herbicide, clodinafop, inhibits ACCase1, the antibiotic thiolactomycin inhibits FabH and FabB/F, the antimicrobial triclosan inhibits FabI and the inhibitor NAS91 inhibits FabZ. 
an antibiotic already evaluated in phase II clinical trails as antimicrobial agent. Fosmidomycin acts rapidly on $P$. falciparum in culture and can cure mice infected by $P$. vinckei. This validated the non-mevalonate pathway as a target for antimalarial drug development. Clinical trials on malaria patients showed a rapid clearance of parasites after seven days of treatment. However, the antibiotic was only partially efficient since a recrudescence was observed in $50 \%$ of cases, certainly due to the short half-life of fosmidomycin (Lell et al., 2003). Research of fosmidomycin derivatives with higher efficiency, longer half-life and better absorption are in progress as well as the study of the other enzymes of the pathway (Singh et al., 2007). Interestingly, fosmidomycin has synergic effect with the antibiotic clindamycin and randomized controlled trials in Gabon showed that the association of both molecules is as efficient as the sulfadoxine-pyrimethamine combination in malaria treatment (Oyakhirome et al., 2007).

\section{REPLICATION, TRANSCRIPTION AND TRANSLATION OF THE PLASTID GENOME}

At least 30 proteins involved in DNA (9) and RNA (10) metabolisms, and protein synthesis (11) have been predicted to be imported into the plastid of $P$. falciparum (Sato \& Wilson, 2005). Antibiotics interfering with bacterial DNA replication, transcription and protein synthesis are thus potential antimalarials. Indeed, several inhibitors of the prokaryotic DNA and RNA machinery (e.g., quinolone antibiotics and rifampicin) or of the prokaryotic protein synthesis (e.g., tetracycline related antibiotics) have a significant antimalarial activity, at least in vitro. But whether they act by targeting processes from bacterial origin in apicoplast or in mitochondria, is difficult to determine. Clindamycin, an inhibitor of peptide bond formation during the elongation cycle of prokaryotic protein synthesis, has been successfully used in combination with other antimalarials to treat uncomplicated cases of malaria (Lell \& Kremsner, 2002). Two classes of antimalarial effectors seem to emerge: fast-acting antibiotics (rifampicin, thiostrepton) with an immediate effect on parasite growth and slow-acting antibiotics (clindamycin and tetracycline) with a parasite delayed-death (no apparent effect on the first erythrocytic cycle but the progeny failed to complete the second erythrocytic cycle) (Goodman et al., 2007). These molecules are however primarily used as antibiotics and their introduction as antimalarials questions their impact on the emergence of bacterial resistances.

\section{HAEM BIOSYNTHESIS}

Malaria parasite depends on de novo synthesis of haem despite acquiring haem from the host red blood cell (Surolia \& Padmanaban, 1992). All the genes of the haem-biosynthetic pathway have been identified in the parasite genome (Padmanaban et al., 2007). Interestingly, the second enzyme in the pathway, the porphobilinogen synthase, is localized into the plastid and has plant-like features that distinguish it from the host enzyme (Sato et al., 2004). Haem biosynthesis was initially proposed to take place in different parasite compartments: mitochondrion and apicoplast. Recently, a more complex scenario was proposed involving, in addition to the intrinsic parasite pathway, an extrinsic haem-biosynthetic pathway in the parasite cytosol that uses imported enzymes of the red blood cell (Padmanaban et al., 2007). What is the importance of such a redundancy among the haem-biosyntheic enzymes for the parasite development? Which is the dominant pathway? These questions need to be answered to exploit this pathway for drug development.

\section{CONCLUSION}

T mportant progresses have been made in defining potential new targets against malaria parasites. Data from the malaria sequenced genomes have considerably contributed to enrich our "reservoir" of targets. In addition to gene products homologous to validated targets in other organisms, virtually, all gene products having no homologous counterparts in human should be considered as putative targets for antimalarial therapy. We are however facing important challenges in the next decade to propose new targets or new lead antimalarial drugs to the pharmaceutical industries. 1) Validation of targets that are essential for the parasite development remains an important limitation. Despite the remarkable advances in genetic of human and rodent Plasmodium (gene insertion or replacement), these technologies remain heavy to undertake, limiting large screenings of genes. However, methodologies for a systematic identification of genes essential for Plasmodium begin to be available (Sakamoto et al., 2005). 2) Ability to propose efficient heterologous expression and folding systems to produce recombinant active proteins for targets, in order to set up assays for screening of inhibitors or to obtain 3D-dimensional structure elucidations using X-ray crystallography for drug design. Importance of this last point was pointed out by Mehlin et al. (2006) who expressed in E. coli 1000 open reading frames from $P$. falciparum: $33 \%$ of these targets were obtained under an insoluble form and only $6.7 \%$ were indeed soluble.

\section{REFERENCES}

Bauer H., Fritz-Wolf K., Winzer A., Kuhner S., Little S., Yardley V., Vezin H., Palfey B., Schirmer R.H. \& DavioudCharvet E. A fluoro analogue of the menadione deriva- 
tive 6-[2'-(3'-methyl)-1',4'-naphthoquinolyl]hexanoic acid is a suicide substrate of glutathione reductase. Crystal structure of the alkylated human enzyme. J. Am. Chem. Soc., 2006, 128, 10784-10794.

Benoit-Vical F., Lelievre J., Berry A., Deymier C., DechyCabaret O., Cazelles J., Loup C., Robert A., Magnaval J.F. \& MeUnIER B. Trioxaquines are new antimalarial agents active on all erythrocytic forms, including gametocytes. Antimicrob. Agents Chemother, 2007, 51, 1463-1472.

Chakrabarti D., Da Silva T., Barger J., Paquette S., Patel H., Patterson S. \& Allen C.M. Protein farnesyltransferase and protein prenylation in Plasmodium falciparum. J. Biol. Chem., 2002, 277, 42066-42073.

Doerig C. \& MEIJER L. Antimalarial drug discovery: targeting protein kinases. Expert. Opin. Ther. Targets, 2007, 11, 279-290.

Eastman R.T., White J., Hucke O., Bauer K., Yokoyama K., Nallan L., Chakrabarti D., Verlinde C.L., Gelb M.H., Rathod P.K. \& VAN VOORHIS W.C. Resistance to a protein farnesyltransferase inhibitor in Plasmodium falciparum. J. Biol. Chem., 2005, 280, 13554-13559.

Eastman R.T., White J., Hucke O., Yokoyama K., Verlinde C.L., Hast M.A., Beese L.S., Gelb M.H., Rathod P.K. \& Van VoORHIS W.C. Resistance mutations at the lipid substrate binding site of Plasmodium falciparum protein farnesyltransferase. Mol. Biochem. Parasitol., 2007, 152, 66-71.

Eckstein-Ludwig U., Webb R.J., Van Goethem I.D., East J.M., Lee A.G., Kimura M., O'neill P.M., Bray P.G., Ward S.A. \& KrISHNA S. Artemisinins target the SERCA of Plasmodium falciparum. Nature, 2003, 424, 957-961.

Flipo M., Beghyn T., Leroux V., Florent I., Deprez B.P. \& Deprez-Poulain R.F. Novel selective inhibitors of the zinc plasmodial aminopeptidase PfA-M1 as potential antimalarial agents. J. Med. Chem., 2007, 50, 1322-1334.

Foth B.J., Ralph S.A., Tonkin C.J., Struck N.S., Fraunholz M., Roos D.S., Cowman A.F. \& Mcfadden G.I. Dissecting apicoplast targeting in the malaria parasite Plasmodium falciparum. Science, 2003, 299, 705-708.

Freundlich J.S., Wang F., Tsai H.C., Kuo M., Shieh H.M., Anderson J.W., Nkrumah L.J., Valderramos J.C., Yu M., Kumar T.R., Valderramos S.G., Jacobs W.R., JR., Schiehser G.A., Jacobus D.P., Fidock D.A. \& Sacchettini J.C. X-ray structural analysis of Plasmodium falciparum enoyl acyl carrier protein reductase as a pathway toward the optimization of triclosan antimalarial efficacy. J. Biol. Chem., 2007, 282, 25436-25444.

Gelb M.H., Van Voorhis W.C., Buckner F.S., Yokoyama K., Eastman R., Carpenter E.P., Panethymitaki C., Brown K.A. \& SMITH D.F. Protein farnesyl and N-myristoyl transferases: piggy-back medicinal chemistry targets for the development of antitrypanosomatid and antimalarial therapeutics. Mol. Biochem. Parasitol., 2003, 126, 155-163.

Goldberg D.E. Hemoglobin degradation. Curr. Top. Microbiol. Immunol., 2005, 295, 275-291.

Golenser J., Waknine J.H., Krugliak M., Hunt N.H. \& Grau G.E. Current perspectives on the mechanism of action of artemisinins. Int. J. Parasitol., 2006, 36, 1427-1441.

Goodman C.D., Su V. \& Mcfadden G.I. The effects of antibacterials on the malaria parasite Plasmodium falciparum. Mol. Biochem. Parasitol., 2007, 152, 181-191.
HydE J.E. Targeting purine and pyrimidine metabolism in human apicomplexan parasites. Curr. Drug Targets, 2007, $8,31-47$.

Jambou R., Legrand E., Niang M., Khim N., Lim P., Volney B., Ekala M.T., Bouchier C., Esterre P., Fandeur T. \& MerceREAU-PUIJALON O. Resistance of Plasmodium falciparum field isolates to in-vitro artemether and point mutations of the SERCA-type PfATPase6. Lancet, 2005, 366, 1960-1963.

Jung M., Kim H., NAm K.Y. \& No K.T. Three-dimensional structure of Plasmodium falciparum $\mathrm{Ca}^{2+}$-ATPase(PfATP6) and docking of artemisinin derivatives to PfATP6. Bioorg. Med. Chem. Lett., 2005, 15, 2994-2997.

Krishna S., Woodrow C.J., Staines H.M., Haynes R.K. \& MerCEREAU-PUIJALON O. Re-evaluation of how artemisinins work in light of emerging evidence of in vitro resistance. Trends Mol. Med., 2006, 12, 200-205.

Labaied M., Dagan A., Dellinger M., Geze M., Egee S., Thomas S.L., WANG C., Gatt S. \& Grellier P. Anti-Plasmodium activity of ceramide analogs. Malar. J., 2004, 3, 49.

Lell B. \& Kremsner P.G. Clindamycin as an antimalarial drug: review of clinical trials. Antimicrob. Agents Chemother., 2002, 46, 2315-2320.

Lell B., Ruangweerayut R., Wiesner J., Missinou M.A., Schindler A., Baranek T., Hintz M., Hutchinson D., Jomaa H. \& KrEMSNER P.G. Fosmidomycin, a novel chemotherapeutic agent for malaria. Antimicrob. Agents Chemother., 2003, 47 , $735-738$

Mambu L. \& Grellier P. Antimalarial compounds from traditionally-used medicinal plants, in: Bioactive natural products. Detection, isolation and structural determination. Colgate S.M. \& Molyneux R.J. (eds), CRC Press, 2007, 491-529.

Mather M.W., Henry K.W. \& VAidya A.B. Mitochondrial drug targets in apicomplexan parasites. Curr. Drug Targets, 2007, $8,49-60$.

MAZumdar J. \& Striepen B. Make it or take it: fatty acid metabolism of apicomplexan parasites. Eukaryot. Cell, 2007, 6, 1727-1735.

Mcrobert L., Jiang S., Stead A. \& Mcconkey G.A. Plasmodium falciparum: interaction of shikimate analogues with antimalarial drugs. Exp. Parasitol., 2005, 111, 178-181.

Menard D., Matsika-Claquin M.D., Djalle D., Yapou F., Manirakiza A., Dolmazon V., Sarda J. \& Talarmin A. Association of failures of seven-day courses of artesunate in a nonimmune population in Bangui, Central African Republic with decreased sensitivity of Plasmodium falciparum. Am J. Trop. Med. Hyg., 2005, 73, 616-621.

Nagamune K. \& Sibley L.D. Comparative genomic and phylogenetic analyses of calcium ATPases and calcium-regulated proteins in the apicomplexa. Mol. Biol. Evol., 2006, 23, 1613-1627.

Nallan L., Bauer K.D., Bendale P., Rivas K., Yokoyama K., Horney C.P., Pendyala P.R., Floyd D., Lombardo L.J., Williams D.K., Hamilton A., Sebti S., Windsor W.T., Weber P.C., Buckner F.S., Chakrabarti D., Gelb M.H. \& Van VoORHIS W.C. Protein farnesyltransferase inhibitors exhibit potent antimalarial activity. J. Med. Chem., 2005, 48, 3704-3713.

O'donnell R.A. \& Blackman M.J. The role of malaria merozoite proteases in red blood cell invasion. Curr. Opin. Microbiol., 2005, 8, 422-427. 
Ohkanda J., Lockman J.W., Yokoyama K., Gelb M.H., Croft S.L., Kendrick H., Harrell M.I., Feagin J.E., Blaskovich M.A., Sebti S.M. \& Hamilton A.D. Peptidomimetic inhibitors of protein farnesyltransferase show potent antimalarial activity. Bioorg. Med. Chem. Lett., 2001, 11, 761-764.

O'Neill P.M., Ward S.A., Berry N.G., Jeyadevan J.P., Biagini G.A., Asadollaly E., Park B.K. \& Bray P.G. A medicinal chemistry perspective on 4-aminoquinoline antimalarial drugs. Curr. Top. Med. Chem., 2006, 6, 479-507.

Oyakhirome S., Issifou S., Pongratz P., Barondi F., Ramharter M., Kun J.F., Missinou M.A., Lell B. \& Kremsner P.G. Randomized controlled trial of fosmidomycin-clindamycin versus sulfadoxine-pyrimethamine in the treatment of Plasmodium falciparum malaria. Antimicrob. Agents Chemother., 2007, 51, 1869-1871.

Padmanaban G., Nagaraj V.A. \& Rangarajan P.N. An alternative model for heme biosynthesis in the malarial parasite. Trends Biochem. Sci., 2007, 32, 443-449.

Sakamoto H., Thiberge S., Akerman S., Janse C.J., Carvalho T.G. \& Menard R. Towards systematic identification of Plasmodium essential genes by transposon shuttle mutagenesis. Nucleic Acids Res., 2005, 33, e174.

Sato S., Clough B., Coates L. \& Wilson R.J. Enzymes for heme biosynthesis are found in both the mitochondrion and plastid of the malaria parasite Plasmodium falciparum. Protist, 2004, 155, 117-125.

SAto S. \& Wilson R.J. The plastid of Plasmodium spp.: a target for inhibitors. Curr. Top. Microbiol. Immunol., 2005, 295, 251-273.

Schirmer R.H., Coulibaly B., Stich A., Scheiwein M., Merkle H., Eubel J., Becker K., Becher H., Muller O., Zich T., SchieK W. \& Kouyate B. Methylene blue as an antimalarial agent. Redox Rep., 2003, 8, 272-275.

Singh N., Cheve G., Avery M.A. \& Mccurdy C.R. Targeting the methyl erythritol phosphate (MEP) pathway for novel antimalarial, antibacterial and herbicidal drug discovery: inhibition of 1-deoxy-D-xylulose-5-phosphate reductoisomerase (DXR) enzyme. Curr. Pharm. Des., 2007, 13, 11611177.

Surolia N. \& Padmanaban G. de novo biosynthesis of heme offers a new chemotherapeutic target in the human malarial parasite. Biochem. Biophys. Res. Commun., 1992, 187, 744-750.

Surolia N. \& Surolia A. Triclosan offers protection against blood stages of malaria by inhibiting enoyl-ACP reductase of Plasmodium falciparum. Nat. Med., 2001, 7, 167-173.

Uhlemann A.C., Cameron A., Eckstein-Ludwig U., Fischbarg J., Iserovich P., Zuniga F.A., East M., Lee A., Brady L., Haynes R.K. \& Krishna S. A single amino acid residue can determine the sensitivity of SERCAs to artemisinins. Nat. Struct. Mol. Biol., 2005, 12, 628-629.

Van Voorhis W.C., Rivas K.L., Bendale P., Nallan L., Horney C., Barrett L.K., Bauer K.D., Smart B.P., Ankala S., Hucke O., Verlinde C.L., Chakrabarti D., Strickland C., Yokoyama K., Buckner F.S., Hamilton A.D., Williams D.K., Lombardo L.J., Floyd D. \& GelB M.H. Efficacy, Pharmacokinetics, and metabolism of tetrahydroquinoline inhibitors of Plasmodium falciparum protein farnesyltransferase. Antimicrob. Agents Chemother., 2007, 51, 3659-3671.
Vennerstrom J.L., Arbe-Barnes S., Brun R., Charman S.A., Chiu F.C., Chollet J., Dong Y., Dorn A., Hunziker D., Matile H., Mcintosh K., Padmanilayam M., Santo Tomas J., Scheurer C., Scorneaux B., TANg Y., Urwyler H., Wittlin S. \& ChARMAN W.N. Identification of an antimalarial synthetic trioxolane drug development candidate. Nature, 2004, 430, 900-904.

Waller R.F., Keeling P.J., Donald R.G., Striepen B., Handman E., Lang-Unnasch N., Cowman A.F., Besra G.S., Roos D.S. \& MCFADDEN G.I. Nuclear-encoded proteins target to the plastid in Toxoplasma gondii and Plasmodium falciparum. Proc. Natl. Acad. Sci. USA, 1998, 95, 12352-12357.

Wengelnik K., Vidal V., Ancelin M.L., Cathiard A.M., Morgat J.L., Kocken C.H., Calas M., Herrera S., Thomas A.W. \& Vial H.J. A class of potent antimalarials and their specific accumulation in infected erythrocytes. Science, 2002, 295, 1311-1314.

Wiesner J. \& JomaA H. Isoprenoid biosynthesis of the apicoplast as drug target. Curr. Drug Targets, 2007, 8, 3-13.

Wiesner J., Kettler K., SaKowski J., Ortmann R., Katzin A.M., Kimura E.A., Silber K., Klebe G., JomaA H. \& Schlitzer M. Farnesyltransferase inhibitors inhibit the growth of malaria parasites in vitro and in vivo. Angew. Chem. Int. Ed. Engl., 2004, 43, 251-254.

WoOdRow C.J. \& Krishna S. Antimalarial drugs: recent advances in molecular determinants of resistance and their clinical significance. Cell. Mol. Life Sci., 2006, 63, 1586-1596. 